\title{
Malay Wisdom in the Motifs of Bamboo Shoots
}

\author{
Safial Aqbar Zakaria ${ }^{1}$ Ramlah Latif ${ }^{2}$, Azizi Bahauddin ${ }^{3}$ \\ ${ }^{1}$ Department of Interior Architecture, School of Housing, Building and Planning, Universiti Sains Malaysia, 11800 Minden, \\ Pulau Pinang, Malaysia \\ ${ }^{2}$ Department of Interior Architecture, School of Housing, Building and Planning, Universiti Sains Malaysia, 11800 Minden, \\ Pulau Pinang, Malaysia \\ ${ }^{3}$ Department of Interior Architecture, School of Housing, Building and Planning, Universiti Sains Malaysia, 11800 Minden, \\ Pulau Pinang, Malaysia
}

\begin{abstract}
The study aims to reveal Malay's philosophical wisdom that is implied in Malay culture. Weaving is a part of Malay culture that is rich in historical and cultural value. Samples of the study are the ikat limar woven cloth, while the focus of the study is the bamboo shoots' motif. Bamboo shoots are one of the motifs synonymous with the ikat limar weaving. The bamboo shoots' motifs are located on the head of the sarong and on the edge of the shawl. Bamboo shoots in a tapered triangular shape is an implementation of the shape of the bamboo stems that appear from the culms. Bamboos are such a plant that brings a lot of benefits to the lives of the Malays from the shoots to the mature canes. The Malays often connect the bamboos with experiences, adulthood, beliefs, as well as pure values that shape the Malay ethos. Bamboo shoots are seen to own a broad sense of cultural philosophies that bring about the existence of sayings, expressions, poem, and figurative speeches. The objectives of the study are to explore the values of Malay wisdom in the motifs of bamboo shoots aside from introducing limar cloth as one of the heritages of Malay wisdom. The methods of the study are interviewing of the aesthetes, experts in textile field as well as those who are related to the textile and cultural field. The qualitative analysis will be used to combine the descriptions, analyses, and interpretations. Based on the outcome of the study, it will become a cultural document and source of reference for the young generations. This study also manages to attract outsiders to recognize and understand the Malay culture as well as getting to know the Malay nature realm.
\end{abstract}

\section{$1 \quad$ Introduction}

Bamboo shoots are one of the motifs that is synonymous within the realm of Malay's visual art. In the design or architecture of Malays' homes, for instance, the design of bamboo shoots is implemented upon the house' ridges or ridge caps. On the weaving of limar cloth and other Malay textiles, bamboo shoots' motifs are usually located on the head part of the sarong and on the both of shawl. The motifs of bamboo shoots are carefully displayed in various organized placement, which illustrates the creativity and competency of the weaver during the ikat benang process to produce such motifs. Such creativity and competency have managed to bring in aesthetical value to the limar cloth. This matter is conveyed through Abdul Hamid (1995), the beauty exists within a lot of objects and the visible objects' beauty can be seen through objects that can be seen. In reference to limar cloth, the object is not only seen upon the design or structure, it also includes the motifs.

The shoots of bamboo shoots are produced through the deep appreciation of the Malays towards the surroundings. It is also said by Ismail (1992) the Malays view some things not only focusing on the material side, they also have a deeper view on the world as seen by them. The statement explains how the Malays see things through physical view and spiritual view. Physical views refer to the tangible or extrinsic objects, while the spiritual views are the instrinsic objects (intangible), Based on this study, limar cloth and bamboo shoots are intangible objects. The meanings, values, or philosophies are the intrinsic values of a limar cloth. 
The relationship of the Malays with nature is so close-knitted. This relationship is explained by how the Malays use natural resources in their daily lives. It demonstrates the existence of wisdom in interpreting the implied nature into work. The nature is a part of the Malays and how it is created is conveyed as a teacher. Through the nature and behaviour, the Malays have managed to produce figurative speeches, sayings, poetry, poems, idioms, and many more. All of this is of important platforms of the Malays in expressing their thoughts. As clarified by Deraman (2000), the Malays have long learned from the nature until such saying is born:

Baik-baik membelah buluh, (Be careful when splitting bamboo)

Dalam buluh ada ulat (There are grubs in bamboo)

Baik-baik mengkaji tubuh (Be careful observing the body)

Dalam tubuh ada sifat (The are characters in the body)

Baik-baik membuang ulat (Be careful when removing the grubs)

Dalam ulat ada sengat (There are stings in the grubs)

Baik-baik mengkaji sifat (Be careful when studying characters)

Dalam sifat ada zat (There are souls in characters)

The saying goes on how the wisdom of the Malays in selecting metaphors by using natural elements which illustrates how detailed they are in observing and grasping meanings. The saying is inclined towards the tasawuf teaching that touches on the spiritual and nature that are unbreakable or inseparable. The arrival of Islam in Malay world has given a new, better perspective to the Malay culture. Islam has shaped the perspectives of the Malays upon a better life by prioritizing knowledge as the core of life in this world and the Hereafter. The Malays are taught to see the world as a creation beneficial in life.

Wisdom of the Malays in "bamboo shoots" is a study to explore and interpret the wisdom of the Malays in relation to bamboo shoots motif. The motifs exist in the variety of objects created by the Malays own a broad sense of meaning and philosophy. Limar cloth is a material or visible object that can be seen and touched, which is fabricated by the Malays through ikat tenun technique.

\subsection{Objectives of the Studies}

The objectives of this study are to discern the wisdom of the Malays in the bamboo shoots motif, and later to comprehend the Malay's values conveyed through the bamboo shoots motifs. Next is to introduce limar cloth as one of the heritage of Malay wisdom.

\subsection{Methods of the Study}

This study also refers to previous studies through literature sources as supporting research findings. Conducting interviews is one of the methods used by interviewing the intellects and individuals involved directly in the culture field and the field of limar cloth weaving. Literature study, interviews and observations were made to support the findings of the study. Library studies refer to previous studies including viewing the source of sayings, expressions, poem and figurative speeches which is the mind of the Malays. Interviews were conducted through open-ended methods. Attention was given to the question of Malay culture, Malay cosmology in the motifs of the limar cloth weaving as part of Malay culture.

An interview was made with Mohamed Najib Ahmad Dawa, an experienced and expansive figure in traditional art, symbols and symbolism in Malay culture, architecture and modern art. Interviews were also made with individuals in Malay woven fields. The two leaders who have been interviewed were Norwani Md. Nawawi, songket experts and weaving specialists. Besides that, an interviewed was made with Manang Wan Awang, the third generation in Malay weaving. These figures are very close to the Malay fine art and have answered the questions of the Malay philosophy in the bamboo shoots as the subjects studied. Interviews were also made with the weavers community to scrutinize the views as well as the weavers' understanding of the chosen motifs. An interview session was held at the National Visual Art Center, Universiti Teknologi Mara (UiTM) and in the village of weaving in Terengganu. Observation was carried out simultaneously to see the nature and nature of the references of bamboo shoots and the activities of the local community reflecting on the meaning and philosophy of the study. Qualitative analysis combines observation and interpretation to the findings of this study. 


\subsection{Definition of Keywords}

In reference with the Kamus Dewan, wisdom gives a sense of courtesy, wisdom, cleverness and caution, intelligence explaining that a tactful person is a sensible person, knowledgeable referring to the meaning of being wise and cautious.

The wisdom of the Malays based on the study is of the courtes of the Malays as well as the values of wisdom, cleverness, caution, that are reflected through the motifs of the bamboo shoot. Motifs according to Bujang and Hamidon (2004) can defined as objects that form the basis of the element in design. Based on this study, motifs are decorative elements in limar cloth. Motifs are a part of the pattern and every motif has a meaning of its own. It becomes a symbol that provide its own value. The Malay culture refer to the ways of thinking, the manners of action received as a value by the Malays and the society which are reflected in the motifs of the bamboo shoots.

Limar cloth is a type of fabric woven by ikat benang method, colour-dyed and woven. Yarns are tied with a rope that can strap or block the color absorption of the strapped yarns. People in the older days used straps of banana heart, taken from banana leaves or banana stems. The yarn knot and the dyed colour form motifs on the fabric after being woven.

Bamboo shoots are located on the head section of the sarong and on both of the shawls.

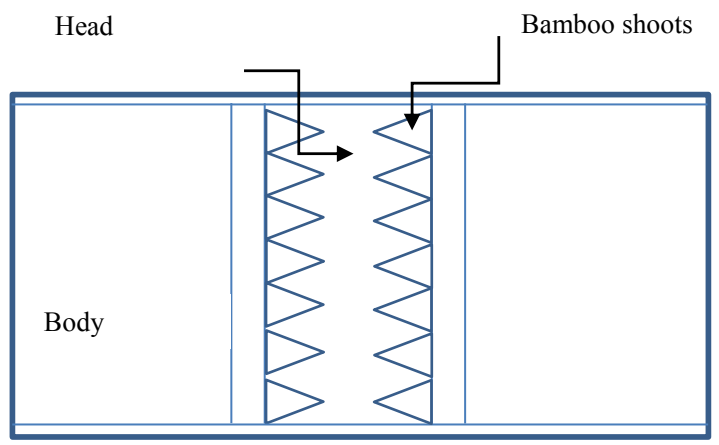

Fig. 1. Location of bamboo shoots on a sarong

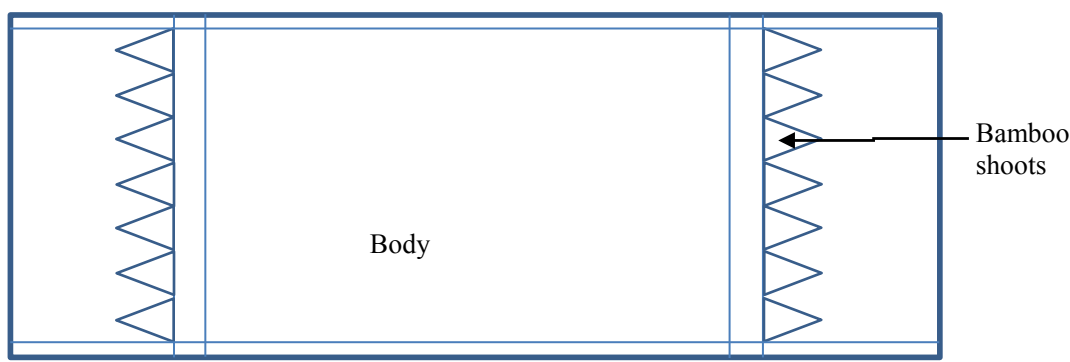

Fig. 2. Location of bamboo shoots on a sarong 


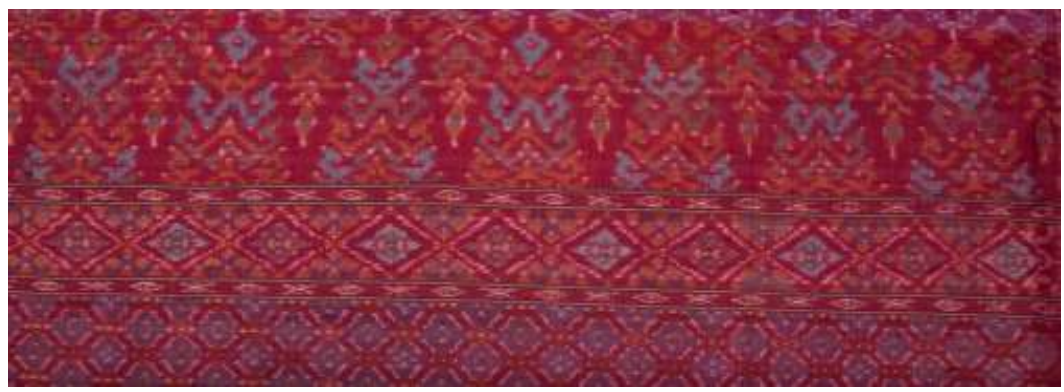

Fig. 3. Bamboo Shoots motifs Source: Terengganu State Muzeum

\subsection{Types of Bamboo Shoots}

A lot of variations and styles of bamboo shoots on limar fabric;

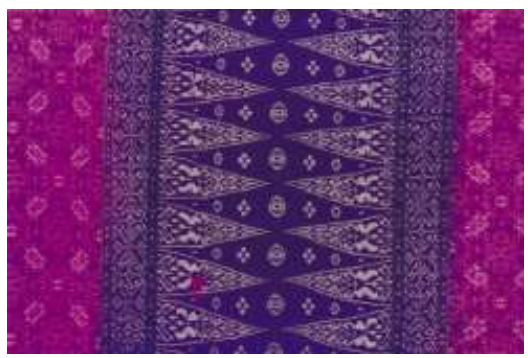

Fig. 4. Lawi itik bamboo shoot with bunga susut sembunyi Source: Muzium Negeri Terengganu.

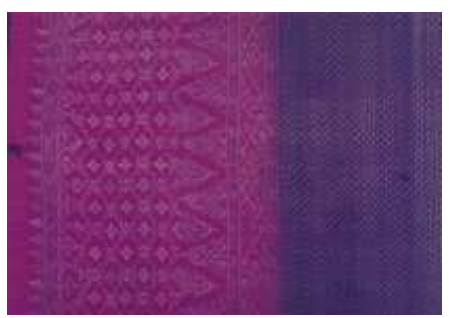

Fig. 5. Kendung Bamboo shoot Source: Terengganu State Muzeum 
Table 1. Styles and characteristics of the variations in bamboo shoots. Source: Md. Nawawi (2016)

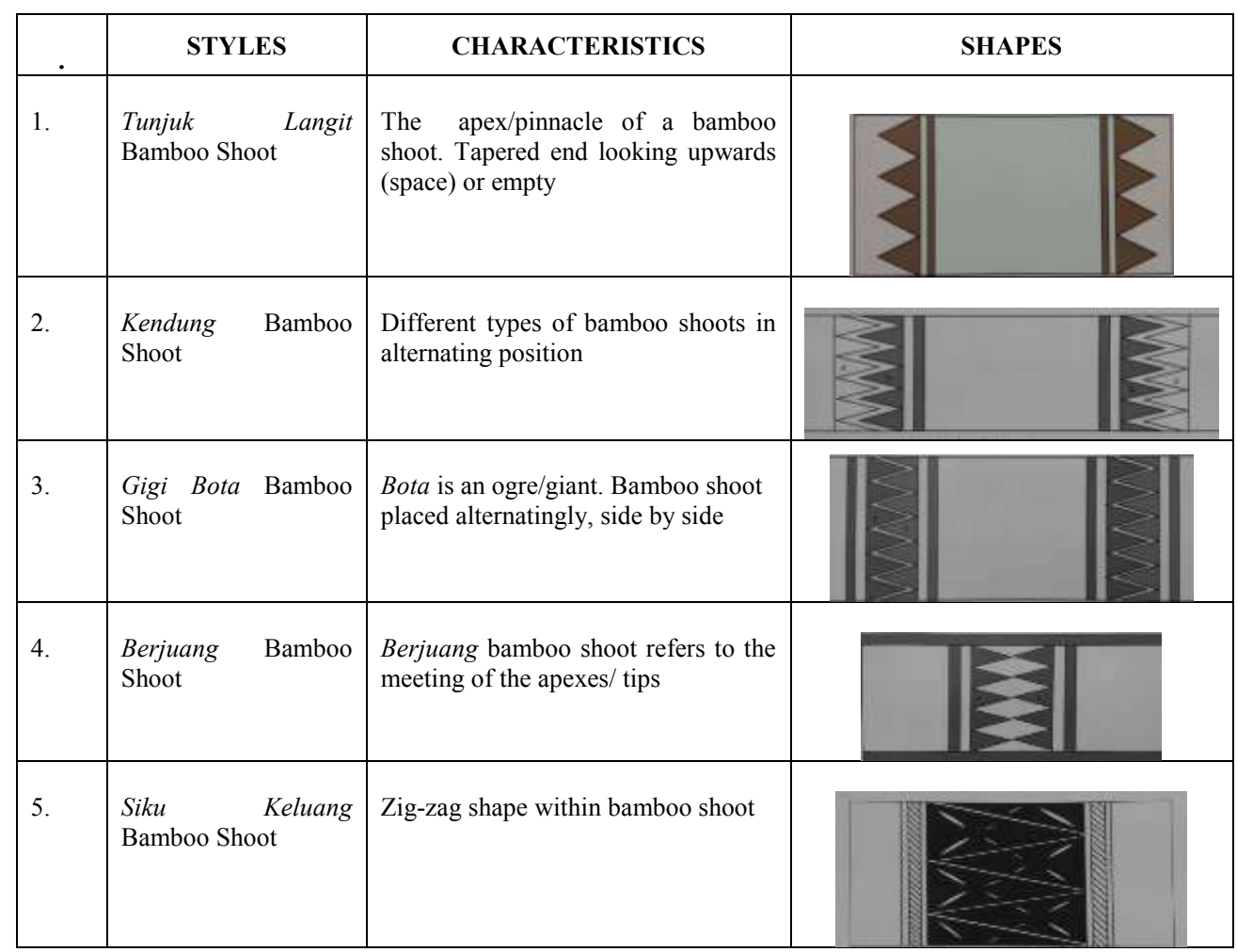

Table 2. Types of bamboo shoots. Source: Md. Nawawi (2016)

\begin{tabular}{|c|c|}
\hline BIL & $\begin{array}{c}\text { TYPES OF BAMBOO } \\
\text { SHOOTS }\end{array}$ \\
\hline 1. & $\begin{array}{lll}\text { Lawi } & \text { Ayam } & \text { Bamboo } \\
\text { Shoot } & & \\
\end{array}$ \\
\hline 2. & Lawi Itik Bamboo Shoot \\
\hline 3. & Kayuhan Bamboo Shoot \\
\hline
\end{tabular}

\section{Discussion}

The Malays often examine the nature in order to produce expressions and life philosophies while implied meanings are reflected through the Malay culture. The culture is connected to the wisdom of the Malays, either tangible materials such as weave, engraving, design, architecture, or the intangible, poetry, poem, sayings, and many others. The world refers to the natures of the fauna and flora as well as the nature of cosmo created for humankind. The world acts as 
the teacher or guide to the Malays which is quoted in the saying "the surrounding world as thy teacher" that is explained by Muhammad Salleh (2006) the Malays think metaphorically by looking at themselves as the nature itself.

Efendy (2004) discusses about the tact and wisdom that are among of the nature of the Malays;

Next,

Arif menyimak kabar burung, (The wise will investigate)

bijak laku dalam bertindak, (Wise when taking action)

Yang arif menjemput tuah, (The wise invites luck)

Yang bijak menjemput maruah, (The clever invites honour)

The value of knowledge is highly regarded by the Malays. Tactful and wise people are fortunate and honourable. Tactful people is highly regarded in a society. This is due to the importances of the wisdom and knowledgeable people as references. That is why they are often elected as leaders in the society as such the saying goes:

Menjadi suluh dalam gelita, (He who enlightens the dark)
Menjadi penawar penolak bias, (Becomes the cure for venom)
Menjadi penenang dalam duka, (Who stays calm in sorrow)
Menjadi penyejuk dalam derita, (Who stays tranquil in agony)
Menjadi penyabar dalam duka. (Who in woe, stays unwearying)

(Efendy, 2004)

In reference with the bamboo shoots, wise people are defined from a lot of aspects based on experiences, observations, and interpretations of the Malays towards the behaviour and nature of the shoot as the foundation of the bamboo. Bamboos come from shoots. The shoots appear amongst the culms. The ability of the shoots to live and grow in the culms give a broad sense of meaning to the lives of the Malays. Bamboo shoots are linked to the perseverance and fighting spirit. Shoots are the soft stems that fight to stay alive amongst the mature canes in the culms. The upper-end tapered part symbolizes focus. This fits the explanation by Bahauddin (1999) which says motifs used are significant with the Malay culture and firmly states that the motifs are related to the concept of fertility, unity, and spirituality. On the other hand, bamboo shoots are related to the concept of nature, as explained the world is by layers. The cosmology of Malay-Hinduism for instance, perceive the cosmos to be consisted with levels and layers, which is the Trailokya (three worlds) concept: the upper realm, the middle realm, and the lower realm.

Zakaria (2015) further explains the layers of the realm refer to the nature of the human life. The world is divided into three symbolized by the bamboo shoot: Real world or universe (Alam Syahadah), Unseen World (Alam Mithal), Spiritual World (Alam Arwah) with the climax is the Divine Essence (Zat Allah). This depicts how wise is of the Malays in providing meaning and interpreting the symbol of bamboo shoots in relation to the greatness of God which become the creed's grasp of the Malays after reverting to Islam as the embraced and accepted religion. The world can be unravelled as follows:

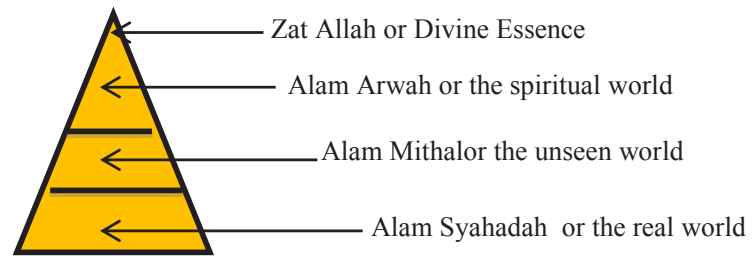

Symbol of Bamboo Shoot

Source: Zakaria (2015)

By referring to the layers above, Real World through the Malays' perspective is a visible world; skies, the earth as well as its substances rivers, hills, mountains inclusive of the Sun, the Moon, stars, oceans, plants and the world as a whole. Unseen World according to the Malays is a space that cannot be seen with naked eyes. Daud (2002) stated that the Malays divide Spiritual World into three, which are fairyland heaven, and hell. Meanwhile, Purgatory encompasses 
the spiritual world. Hereafter world, and the world before being born into the Earth. Divine Essence, the highest elevation of the Creator, the Almighty, remains as stated in the Quran, surah Al-Rahman (55);

\section{"Segala yang dimukabumi akan binasa;yang kekal adalah zat Tuhanmu Yang mempunyai kebesaran dan kemuliaan."}

Surahal_Rahman (55), ayat 26-27.

"Everything in this world will perish, And there will remain the Face of your Lord, Owner of Majesty and Honour"

$$
\text { Ar-Rahman (55), verse 26-27 }
$$

Islam teaches the Malays on how to stay humble, recognizing that as a impermanent human and servant in this world, death is inevitable and everything that we hold dearly and proudly will be left behind. Islam seeping into a Malay perfects the modesty culture of the Malay. This is explained by Ahmad Jamal (1992), the most obvious cultural aspects of Malays' are the sense of modesty, staying humble and not boasting around about his or her expertise or wealth. The sense of humility is the essence of a traditional Malay society.

A bamboo shoot in a triangular shape according to Bahauddin (1999) explains there are four elements orderly arranged inside our bodies or humanself.

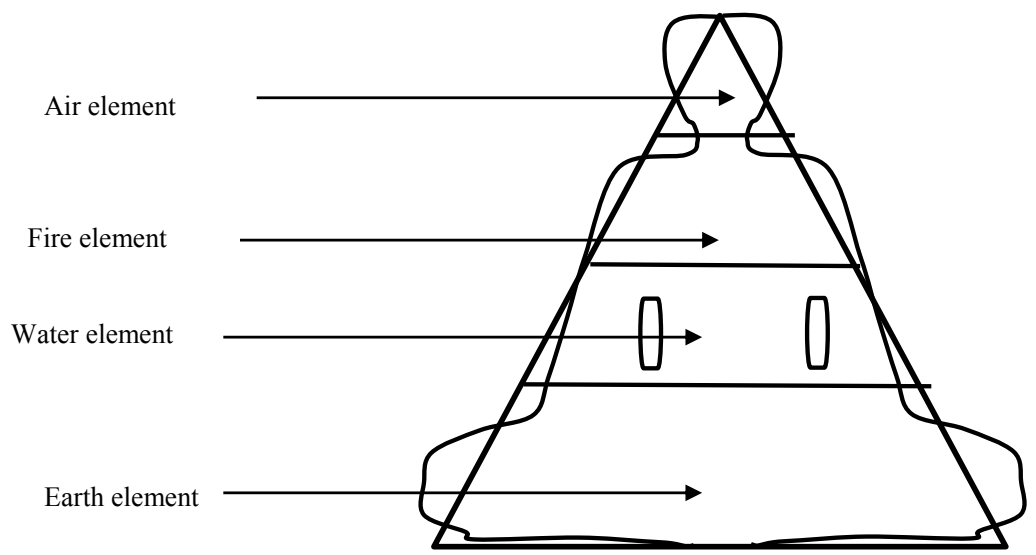

The contemporary Malaysian Arts: An Exploration of the songket motifs. Source: Azizi Bahauddin (1999).

According to the views' of the Malays, the creation of the universe and humankind itself originated from four essentials or elements; earth, water, fire, and wind which inhibit the nature of cold, humid, hot, and dry. Seyyed Hosein Nasr (1993) states that the four elements and essentials develop ourself, which is known as microcosm.

On another words, bamboo shoots symbolize the process of personal development and self-development since young. Early childhood education plays an important role in shaping one's personal characteristics of becoming competent individuals to the society. According to Muhammed Najib Dawa via an interview, shoots personify a growing young child. Meanwhile, the bamboo symbolizes an adult. Adults are subjected as reference to the children. The Malays relate competent individuals whom are taught since young will be able to benefit the society as they grow older. For instance, the bamboos are made as walls, floors, roof bars, stairs as well as being used outside as fences, bridges, which often used by farmers and fishermen. At rivers, bamboos are designed as rafts, fish traps (bubu) or tembilar (similar to $b u b u$ ), as well as being made into nesting box for the hens to lay and brood eggs. The importances of shoots maturing denote men who are beneficial and significant to the society like the saying goes: 
Karam di laut jadi pelampung,

Panas di darat jadi penaung,

Basah di hilir jadi penudung,

Patah di hulu jadi penyambung.

Foundered in the sea, stayed afloat,

Blazed onshore, acted as a support,

Drenched downstream, perched with a hood

Broken upstream, befitted a bridge.

(Seyyed Hosein Nasr, 1993)

The wise Malays in examining bamboo shoots in various aspects of Malays' lives by looking through the nature, actions, and characters of bamboo shoots. Bamboo sprouts are bamboo stems grown amongst the bamboo culms. Bamboos can be preserved and cooked as appetizing dishes. Bamboo sprouts are symbolized as children whom are growing into adulthood.

To bend a bamboo, while it is still a shoot, this saying explains that bamboos are easily bent while they are still shoots. This shows the metaphorical ways of thinking of the Malays in establishing the nature as their teacher. In the Malay architecture for instance, bamboo shoots' motifs are visible upon the shape of the roof ridge of their houses. The triangular shape of the ridge is the bamboo shoot's shape that is related to the highest authority in this layered world, which is of the essence of Allah, as stated by Zakaria (2015) in the philosophy of bamboo shoots. In the everyday life of the Malays, the highest place is the roof of a house. It is tantamount to the Head, which is honourable for the Malays hence why it is intolerable to toy with their heads.

The ridge of a Malay house is an honourable and elevated place. The highest place demonstrates the place of the powerful and exalted essence. It is where the brain is located, which is used to think and decide upon rational actions. The Malays honour the matters related to humans' heads. Head accessories such as kopiah (kopeah) and songkok are often placed at the highest location that cannot be trampled upon or walked over. These behaviours displayed above show the perspectives of the Malays in regards with the importances of honouring knowledge as they regard highly the heads and matters relating to it.

\section{Conclusion}

The wisdom of the Malays in regards with bamboo shoots were reflected through personification, meanwhile, the struggle could be interpreted through the bamboo shoots' characters that emerged and became matured amongst the older canes. The strong philosophical belief of Malays in the essence of the Creator was explained through the nature hierarchy, starting from the real world to the essence of the Almighty at the highest elevation. This unfolded the humility of the Malays, which often realized that human life is fleeting, worldly gratifications will be left behind, the only that will remain is the Creator. The interpretations of values and philosophies in bamboo shoots' motifs had demonstrated the prudence of the Malays in scrutinizing and defining the world represented by bamboo shoots.

\section{References}

1. Abdul Hamid, Hamidah. (1995). Pengantar Estetik. Kuala Lumpur: Dewan Bahasa dan Pustaka. p, 5.

2. Ahmad Jamal, Syed. (1992). Rupa dan Jiwa. Kuala Lumpur: Dewan Bahasa dan Pustaka. p, 2.

3. Bahauddin, Azizi. (1999). The contemporary Malaysian Arts: An Exploration of the songket motifs. Tesis Doktor Falsafah ( Ph.D), Sheffield Hallam University.

4. Borhan, Zainal Abidin. (2006). Pantun Dalam Ungkapan Serta Pandangan Sementara Melayu dalam Pandangan Semester Melayu. Kuala Lumpur: Dewan Bahasa Dan Pustaka. p, 247.

5. Bujang, Rahimah \& Hamidon, Nor Azlin. ( 2004). Kesenian Melayu. Kuala Lumpur: Universiti Malaya. p, 96.

6. Daud, Harun. (2002). Pemikiran Melayu tentang Alam dan Hakikat Diri in Syed Muhammad Dawilah al-Edrus, Pemikiran Melayu tentang Alam dan Hakikat Diri. Kumpulan Kertas Kerja Kolokium Bahasa dan Pemikiran Melayu /Indonesia II. Kuala Lumpur: Dewan Bahasa dan Pustaka. p, 115-137.

7. Deraman, Aziz. (2000). Tamadun Melayu dan Pembinaan Bangsa Malaysia. Kuala Lumpur: Dewan Bahasa dan Pustaka. p, 30. 
8. Effendy, Tenas. (2000). Pemimpin Dalam Ungkapan Melayu. Kuala Lumpur: Dewan Bahasa Dan Pustaka. p, 8 .

9. Effendy, Tenas. (2004).Corak dan Ragi Tenun Melayu Riau. Jogyakarta: AdiCita. p, 83, 87.

10. Ismail, Moktar. (1992). Rumah Tradsisional Melayu Melaka. Kuala Lumpur: Persatuan Muzium Malaysia. p, 49,51 .

11. Ismail, Siti Zainon. (2006). Pakaian Cara Melayu. Bangi: Universiti Kebangsaan Malaysia. p, 235. Kamus Dewan Edisi Ketiga, (1996) Kuala Lumpur: Dewan Bahasa Dan Pustaka, p, 815.

12. Md. Nawawi, Norwani. (2016). Ikat Limar The Ancient Malay Textile.Kuala Lumpur: Dewan Bahasa dan Pustaka. p, 12.

13. Md. Nawawi, Norwani. (2017, April 28). Motif-motif dalam Tenunan Kain Limar (Interview).

14. Mohd Yusoff, Zulkifli. (2010) Kamus Lengkap Al-Quran.Kuala Lumpur: PTS Publishing House.

15. Mohamed Najib Dawa. (11 March 2016). Falsafah dan simbol motif-motif seni tampak Tempatan (Interview).

16. Muhammad Salleh. (2006). Dalam Daun Ada Bicara:Falsafah Alam Pantun Melayu. Kuala Lumpur: Dewan Bahasa \& Pustaka. p, 1-34.

17. Seyyed Hossein Nasr (1993) Pengenalan Doktorin Kosmologi Islam. Kuala Lumpur: Dewan Bahasa Dan Pustaka. p, 167.

18. Wan Manang. (2016, June 12). Falsafah Motif Kain Limar (Interview).

19. Wan Daud, Wan Mohd Nor. (2005) Kerangka Keilmuan Tamadun Melayu: Satu Cerminan Ketamadunan. Kuala Lumpur :Dewan Bahasa Pustaka. p, 98-120.

20. Zakaria, Safial Aqbar. (2015). The Interpretation of Light in Bamboo Shoot Malay Songket motif. Thesis (Ph.D). Universiti Sains Malaysia. 